\title{
Synchroneity of folding and crosscutting cleavage in the Newfoundland Appalachians?
}

\author{
Ben A. van der Pluijm \\ Department of Geological Sciences, University of Michigan, 1006 C.C. Little Building. Ann Arbor, \\ MI 48109, U.S.A.
}

(Received 21 December 1989; accepted in revised form 20 April 1990)

\begin{abstract}
Cleavage that cuts obliquely across folds is relatively common in the Appalachians/Caledonides and this has been interpreted as evidence for regional transpression, an interpretation which is only valid if contemporaneity of folding and cleavage formation can be demonstrated. Crosscutting cleavages in folds of the Early Silurian and older Exploits Group of the northeastern Newfoundland Appalachians are axial planar to rare, mesoscopic $F_{2}$ fold in the unconformably overlying Botwood Group on Change Islands. As an alternative to transected folds, it is argued that crosscutting cleavage relationships in the Exploits units are composite $D_{1}-D_{2}$ structures that represent fold superimposition.
\end{abstract}

\section{INTRODUCTION}

IN RECENT years, folds transected by their cleavage have received considerable attention (e.g. Borradaile 1978, Treagus \& Treagus 1981, Soper 1986). In the Appalachian/Caledonian chain, non-axial planar or transecting cleavages have been reported by several authors (e.g. Stringer 1975, Sanderson et al. 1980, Stringer \& Treagus 1980, Blewett \& Pickering 1988, 1989). This geometry has been used as primary evidence for major strike-slip motion that accompanied regional shortening (e.g. Sanderson et al. 1980, Soper \& Hutton 1984, Woodcock et al. 1988; cf. Lafrance 1989, Lafrance et al. 1989). However, in addition to the characteristic geometric relationship, this interpretation requires that cleavage formation and folding occurred roughly contemporaneously (Williams 1985, Soper 1986).

In this note, I will describe an example of structural geometry from Change Islands in the northeastern part of the Newfoundland Appalachians, where the regional cleavage crosscuts folds in Early Silurian and older rocks, but is axial planar to locally preserved mesoscopic folds in mid-Silurian rocks. The latter occurrence is not reported (rare?) elsewhere in the Appalachians/Caledonides, but is very important for the interpretation of widely present crosscutting cleavage-fold relationships in the orogen. No effort is made in this contribution to interpret the significance of these deformation patterns for Appalachian geology (see van der Pluijm \& van Staal 1988 , van der Pluijm et al. in press). I will use the term transecting cleavage for crosscutting cleavage assumed to be roughly synchronous with folding and just crosscutting cleavage to describe this geometry without the temporal connotation.

\section{STRUCTURAL GEOMETRY}

In the Central Mobile Belt of northeastern Newfoundland, $D_{1}$ deformation is widely present in grey- wackes and conglomerates of the Upper Ordovician to Lower Silurian Exploits Group (Karlstrom et al. 1982, van der Pluijm 1986). $D_{1}$ folding and thrusting is associated with the formation of an accretionary complex in the central part of the orogen. Subsequent deformation $\left(D_{2}\right)$ folded low-angle reverse faults of the complex. Commonly, mesoscopic folds in greywackes are crosscut by the steeply-dipping regional slaty cleavage (e.g. Blewett \& Pickering 1988, Lafrance 1989) of Late Silurian-Early Devonian age. In Fig. 1 a particularly well-exposed example of this relationship from the Change Islands is shown. On folded bedding surfaces, the angular difference between cleavage traces and the fold axis is apparent. In map view (the horizontal surface), the regional cleavage consistently cuts across bedding in a counterclockwise sense. In profile, however, the cleavage appears to be axial planar to these folds. Measurements of the poles to bedding in these greywackes define a girdle that trends NNE, with the corresponding fold axis at $10^{\circ} / 277^{\circ}$ (Fig. 2a).

Mid-Silurian subaerial volcanics and micaceous sandstones of the Botwood Group overlie the Exploits Group greywackes with angular unconformity (van der Pluijm et al. in press). The Botwood is folded in relatively open, upright structures with wavelengths that range from several meters to kilometers; in the micaceous sandstones an axial-plane cleavage is well developed. Measurements of poles to bedding in the Botwood Group along the west coast of Change Islands define a girdle that trends NNW, with a regional fold axis at $05^{\circ} / 249^{\circ}$ (Fig. 2b). The cleavage orientation in Botwood sandstones and Exploits greywackes clusters around a well-defined maximum $\left(167^{\circ} / 66^{\circ}\right.$, Fig. $\left.2 \mathrm{c}\right)$, which indicates an axial-plane relationship between Botwood folds and the regional cleavage. In contrast, an angular difference of $20^{\circ}$ (angle $\Delta$ of Borradaile 1978) exists between the calculated fold axis for the Exploits Group and the cleavage (Fig. 2c), which is consistent with local field observations (e.g. Fig. 1). 


\section{DISCUSSION}

Two characteristic fold-cleavage relationships are recognized in the Early Silurian and older Exploits Group, and the unconformably overlying mid-Silurian Botwood Group of the northeastern Newfoundland Appalachians. One finds (1) open folds in the Botwood Group whereas tight to isoclinal folds dominate the Exploits Group, and (2) the regional cleavage is parallel to the axial plane of folds in Botwood sandstones, but cuts obliquely (counterclockwise) across folds in the Exploits Group. Shallow- to intermediate-dipping beds with a well-developed cleavage are characteristic for the Botwood Group, but associated mesoscopic folds are rarely exposed in areas outside Change Islands. The structural geometry of northeastern Newfoundland, therefore, is dominated by crosscutting fold-cleavage relationships that characterize the structures of the Exploits Group.

The occurrence of crosscutting cleavages in folded greywackes may be construed as evidence for transected folds and, thus, be used to conclude an overall transpressional regime during folding. Alternatively, the crosscutting cleavage may represent non-coaxial, superimposed $D_{2}$ deformation based on the geometric relationship between cleavage and Botwood folds described in the previous section. In this alternative scenario, $D_{2}$ deformation folded subhorizontal units of the Botwood Group and was accompanied by penetrative cleavage formation $\left(S_{2}\right)$. Superimposed $S_{2}$ deformation may have, thus, resulted in tightening of existing $D_{1}$ structures, which in turn became composite $D_{1} / D_{2}$ structures, and produced the observed crosscutting foldcleavage relationship in units of the Exploits Group.

Acknowledgements-Julie Gales is thanked for field assistance and the Bown's of Change Islands for generous hospitality. Dave Sanderson is thanked for discussion, and Jack Soper, Peter Stringer, Sue Treagus, Peter Vrolijk and an anonymous referee for helpful reviews. Research was supported by NSF grant 89-05811 and a Rackham Faculty Grant.

\section{REFERENCES}

Blewett, R. S. \& Pickering, K. T. 1988. Sinistral shear during Acadian deformation in north-central Newfoundland, based on transecting cleavage. J. Struct. Geol. 10, 125-127.

Blewett, R. S. \& Pickering, K. T. 1989. Sinistral shear during Acadian deformation in north-central Newfoundland, based on transecting cleavage: Reply. J. Struct. Geol. 11, 366-368.

Borradaile, G. J. 1978. Transected folds: a study illustrated with examples from Canada and Scotland. Bull. geol. Soc. Am. 89, 481493.

Karistrom, K. E., van der Pluijm, B. A. \& Williams, P. F. 1982. Structural interpretation of the eastern Notre Dame Bay area Newfoundland: regional post-middle Silurian thrusting and asymmetrical folding. Can. J. Earth Sci. 19, 2325-2341.

Lafrance, B. 1989. Structural evolution of a transpression zone in north central Newfoundland. J. Struct. Geol. 11, 705-716.

Lafrance, B., Williams, P. F. \& Elliott, C. G. 1989. Sinistral shear during Acadian deformation in north-central Newfoundland, based on transecting cleavage: Discussion. J. Struct. Geol. 11, 365-366.

Sanderson, D. J., Andrews, J. R., Phillips, W. E. A. \& Hutton, D. H 1980. Deformation structures in the Irish Caledonides. J. geol. Soc. Lond. 137, 289-302.

Soper, N. J. 1986. Geometry of transecting, anastomosing solution cleavage in transpression zones. J. Struct. Geol. 8, 927-940.

Soper, N. J. \& Hutton, D. H. W. 1984. Late Caledonian sinistral displacements in Britain: implications for a three-plate model. Tectonophysics 3, 781-794.

Stringer, P. 1975. Acadian slaty cleavage noncoplanar with fold axial surfaces in the northern Appalachians. Can. J. Earth Sci. 12, 949961.

Stringer, P. \& Treagus, J. E. 1980 . Non-axial planar $S_{1}$ cleavage in the Hawick rocks of the Galloway area, Southern Uplands, Scotland. $J$. Struct. Geol. 2, 317-331.

Treagus, J. E. \& Treagus, S. H. 1981. Folds and the strain ellipsoid: a general model. J. Struct. Geol. 3, 1-17.

van der Pluijm, B. A. 1986. Geology of eastern New World Island, Newfoundland: an accretionary terrane in the northeastern Appalachians. Bull. geol. Soc. Am. 97, 932-945.

van der Pluijm, B. A., Johnson, R. J. E. \& Van der Voo, R. In press. Ordovician and Silurian history of the northern Appalachians: paleogeography, timing of accretion and tectonic scenario. Spec. Pap. geol. Soc. Am.

van der Pluijm, B. A. \& van Staal, C. R. 1988. Characteristics and evolution of the Central Mobile Belt, Canadian Appalachians. J. Geol. 96, 535-547.

Williams, P. F. 1985. Multiply deformed terrains-problems of correlation. J. Struct. Geol. 7, 269-280.

Woodcock, N. H., Awan, M. A., Johnson, T. E., Mackie, A. H. \& Smith, R. D. A. 1988. Acadian tectonics of Wales during Avalonia/ Laurentia convergence. Tectonophysics 7, 483-495. 

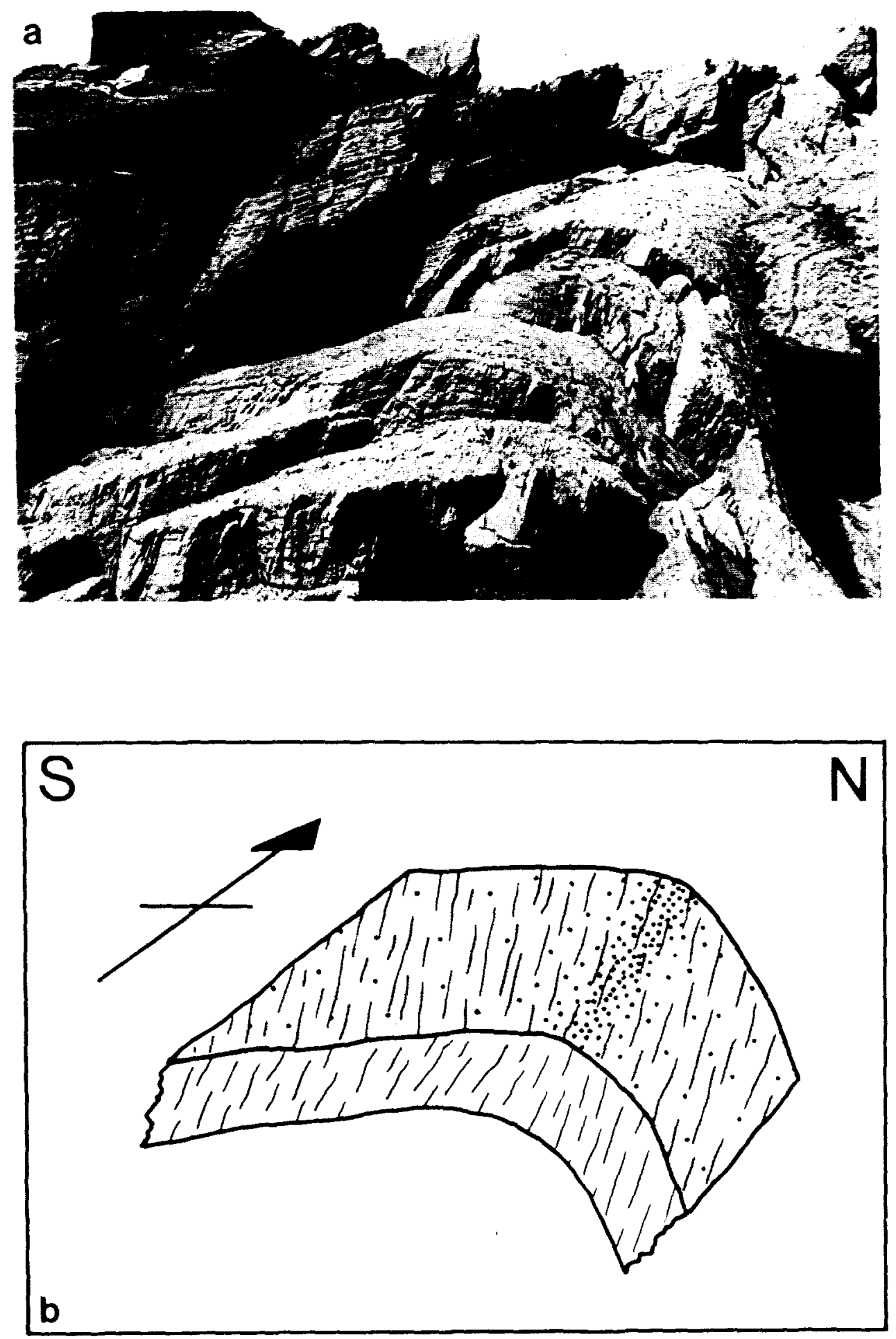

Fig. 1. (a) Field photograph of fold-cleavage relationship in greywackes of the Exploits Group on western Change Islands (at Randell's Head); notebook $(19 \times 12 \mathrm{~cm})$ for scale. (b) A schematic drawing of the characteristic relationship between bedding and cleavage. Band of dots indicates fold axis. 


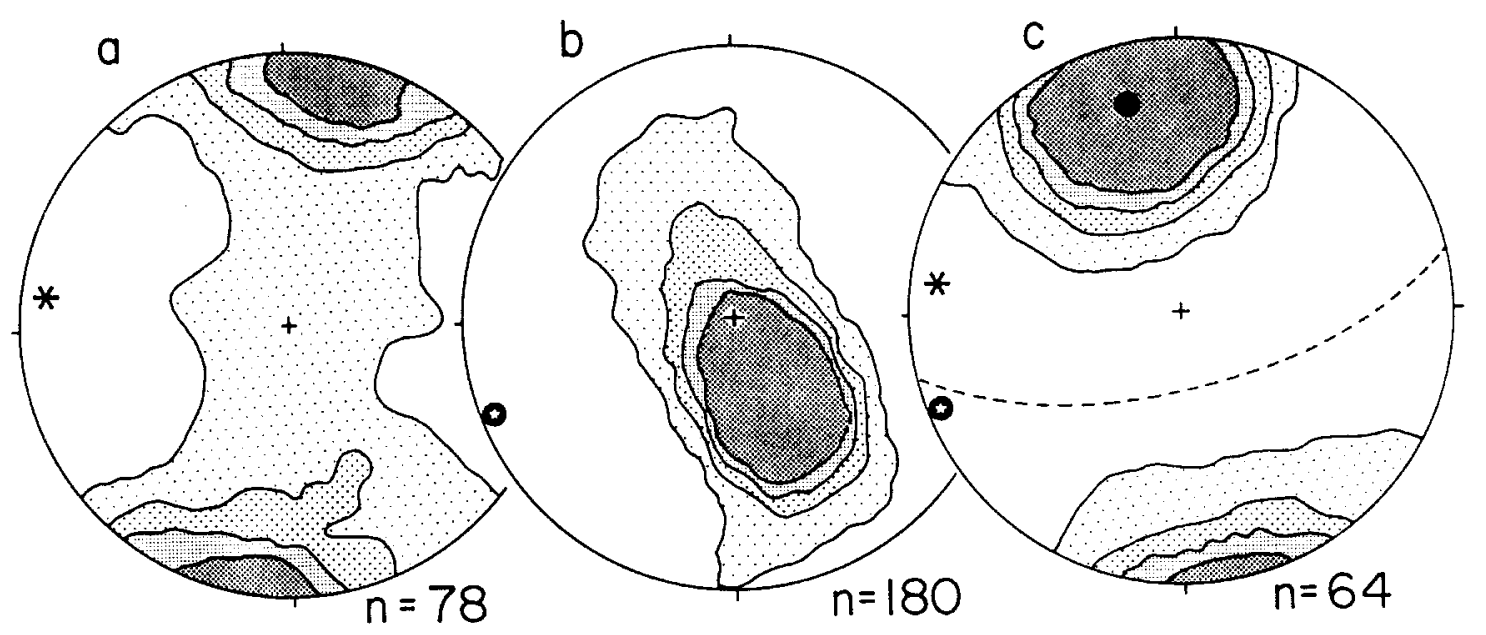

Contours
* Calculated fold axis in greywackes
$\therefore 1-3$
- Calculated fold axis in Botwood Group
3-6
- mean cleavage pole

$7-9$
$>10$

Fig. 2. Lower-hemisphere, equal-area projections of (a) poles to bedding in predominantly greywackes of the Exploits Group, (b) poles to bedding in predominantly sandstones of the unconformably overlying Botwood Group and (c) poles to the regional slaty cleavage and the mean cleavage plane (dashed line). The small angular difference between the mean cleavage plane and the calculated Botwood fold axis $\left(c a 5^{\circ}\right)$ is considered to be within error. Projections are contoured using the Kamb method; number of standard deviations are given. 